\title{
The Role of Islamic Education Teachers Competency in Improving the Quality of Education
}

\author{
Zuhaeriah Zuhaeriah ${ }^{*}$, Moh. Ali ${ }^{2}$, Yusra Yusra ${ }^{3}$ \\ ${ }^{1}$ Islamic Education Department, Postgraduate, Institut Agama Islam Negeri Palu \\ 2 Islamic Education Department, Postgraduate, Institut Agama Islam Negeri Palu \\ ${ }^{3}$ Islamic Education Department, Postgraduate, Institut Agama Islam Negeri Palu
}

\section{ABSTRACT}

This study discusses the urgency of the competency of teachers on the subjects of Islamic religious education. This study used descriptive qualitative method and gather data through observation, interview, and documentation. Data analysis was carried out through reduction, data presentation, and data verification that ended with checking the validity of the data. The results of this study shows that competence of teachers in junior high school is adequate. The role of teachers in improving the quality of teaching, positions which directly determine the success, considering the teacher as a figure who is directly involved in learning in the classroom. All of these roles requires more concrete effort, and directly touch to the needs of students in order to get better the quality of learning. The efforts made by the Islamic religious education teachers in improving the quality of education including the provision of guidance to students, advice, supervision of students, providing motivation and rewards, using varied teaching methods, and personal approach to students. Supporting factors include the existence of good cooperation from principals, teachers, parents, staff, students and the local community, the infrastructure, the competent teachers, and safe and orderly environment. Inhibiting factors include the lack of instructional media; in this case the writer mean is computer and LCD, the lack of participation and support fromstudents' parent. As for efforts to deal with is as follows: add computer and LCD and establish good coordination with parents.

\section{ARTICLE \\ INFORMATION}

Keywords:

Islamic education, teachers' competency, education quality 


\section{Introduction}

Competence is the ability to carry out a task/work based on knowledge, skills, and attitudes in accordance with the required performance. Competence for several professions is an important requirement in carrying out the framework and objectives of the organization. The issue of competence is important because competency offers an organizational framework that is effective and efficient in utilizing limited resources. In every job and profession, especially in the field of education in schools' scope, the main education personnel must be teachers who have competencies in accordance with their fields and responsibilities. Teachers who have competence in their profession will be able to carry out their duties properly and efficiently, effectively, on time, and following the objectives.

According to Syaiful Sagala, competence is a fusion of knowledge (power of thought), attitude (the use of heart), and skills (physical power), which are manifested in the form of actions. In other words, competence is a combination of mastery of knowledge, skills, values, and attitudes reflected in the habits of thinking and acting in carrying out their duties or work. It can also be said that competence is a combination of ability, knowledge, skills, attitude, character, understanding, appreciation, and expectations that underlies a person's characteristics to demonstrate work in explaining a task or job in order to achieve quality standards in real work. So, competence is a set of knowledge, skills, and behaviors that must be possessed, internalized, and mastered by the teacher to be able to carry out professional tasks. ${ }^{1}$

The purpose of education is determined not only by the school but also by its structure, content, and curriculum is also largely determined by the competence of teachers who teach and guide students. If the teacher is analogized with a spear, then the teacher is the double-edged spear. One eye must have the sharpness in mastering the material and the nature of the knowledge to be taught, while the other one sharp eye is because it has the ability or skills in gathering and presenting the material so that students can learn meaningfully, and provide usefulness that can be felt from the learning process that follows. ${ }^{2}$

As an essential element in educational institutions, teachers as instructors are expected to have competencies in accordance with their teaching fields. This, at least, has implications for the ease of transferring knowledge to students, indicating the presence of pleasure and "curiosity" in learning. Thus, internally the motivation of learners will raise a penchant for learning and always training themselves to be problem-solving in the problems faced.

Teachers play a major role in the development of education, especially Islamic Religious Education teachers.

1 Oemar Hamalik, Pendidikan Guru Berdasarkan Pendidikan Kompetensi, (Jakarta; PT Bumi Aksara, 2009), 39.

2 Isjoni, Guru sebagai Motivator Perubahan, ( Yogyakarta: Pustaka Pelajar, 2009), Cet. 2. 13.

e-ISSN: 2715-4572

p-ISSN: 2716-1439 
Therefore, any improvement efforts made in an effort to improve the quality of education will not make a significant contribution without the support of professional and qualified teachers. ${ }^{3}$

Based on observations, on preliminary observations at the SMP 10 Palu, the values in the formation of the character of students, educators who are in the SMP 10 Palu have fully implemented efforts in developing the implementation of the character formation of students based on in terms of moral values.

As the results of the author's interview with the coordinator of Islamic Religious Education subjects related to the competencies of Islamic Religious Education teachers as follows:

The Islamic Religious Education teacher numbered four people and already has four competencies as listed in the National Education System Law, which is: pedagogical competence, professional competence, competence, personality competence. ${ }^{4}$

Educators, especially Islamic Religious Education teachers, have various competencies obtained from professional teacher education that are relevant to their duties and responsibilities. This should be able to be mastered with effective learning

3 E.Mulyasa, Standar Kompotensi dan sertifikasi Guru (Cet: I; Bandung: PT Remaja Rosdakarya, 2007), 5.

4 Siti Jawariah, Wawancara Koordinator Guru Pendidikan Agama Islam (PAI), 2 Februari 2015. methods and is able to apply in learning planning models, understand the curriculum properly making learning tools, implement learning in class, be a model of students, train and guide students towards the achievement of goals and examples of noble examples and examples and so forth.

In this study, the reason the author took place at the SMP 10 Palu as a location for scientific research based on several considerations based on initial observations on Saturday 27 January 2015.

First, educators who are in the SMP Negeri 10 Palu already have a variety of competencies and have implemented the best skills they have, and it's just everything else especially related to humans, which in this case educating students does require energy and extra thinking.

Secondly, looking at the condition of the students in the SMP Negeri 10 Palu in accepting new students, not through screening where every student who registers at the school is accepted. Thus, the teachers in the SMP Negeri 10 Palu, especially Islamic Religious Education teachers, try their best to educate and shape students so that they can have three domains: cognitive, affective, and personality.

\section{Literature Review}

\subsection{Concept of Teacher Competency}

The word competency can be interpreted as an ability. This word is now the key to education. In the 
curriculum, for example, we know CBC (Competency-Based curriculum). ${ }^{5}$

Competence is the authority (power) to determine (decide something). ${ }^{6}$ In English, competency is an underlying characteristic of an individual that is causally related to criterionreferenced effective and superior performance in job or situation. ${ }^{7}$

"Competence is the ability, skills possessed by a person, and skills possessed by a person regarding his duties, positions and profession."8 Meanwhile, based on the Law Article 3 paragraph 1, it is explained that competency is a set of knowledge, skills, and behaviors that must be possessed, internalized, and mastered by teachers and lecturers in carrying out their professional duties. ${ }^{9}$

Competence is something that describes a person's qualifications or abilities, both qualitative and quantitative. Competence is also defined as knowledge, skills, and abilities mastered by someone who has become a part of him so that he can perform

5 Ngainum Naim, Menjadi Guru yang Inspiratif, (Yogyakarta:Pustaka Pelajar, 2011), 56.

6 Tim penyusun kamus pusat bahasa, Kamus besar bahasa Indonesia ( Jakarta: Balai Pustaka,2005), edisi.3, 584.

7 Jhopn Whiley and sons,inc, Competence at work, (Canada: Published simultaneously), 9.

8 Trianto, Pengantar Penelitian Pendidikan bagi Pengembangan Profesi Pendidikan dan Tenaga Kependidikan, (Jakarta: Prenada Media Group,2010), 53.

9 Ngainum Naim, Menjadi Guru yang Inspiratif, 228. cognitive behaviors, effectively, and psychomotor as well as possible. ${ }^{10}$

From the information above, it can be concluded that the teacher's competence is the teacher's ability to carry out his teaching profession. Teacher Competencies referred to in Law of the Republic of Indonesia No. 14 of 2005 concerning Teachers and Lecturers on article 3 paragraph 1 that states, "teacher competencies include pedagogical competencies, personal competencies, social competencies, and professional competencies obtained through professional education."11 So if the teacher mastered the four competencies, the teacher will carry out their duties and responsibilities independently and as well as possible.

The teacher is the most decisive component in the overall education system. This figure will always be a strategic spotlight when talking about educational issues. Teachers play a major role in educational development, especially those that are held formally in schools. $^{12}$ Teachers determine the success of students in relation to the learning process. Teachers are the most

\footnotetext{
10 Kunadar , Guru profesional Implementasi Kurikulum Tingkat Satuan (KTSP), (Jakarta: PT Raja Grafindo,2007), 51.

11 "Undang-Undang RI Nomor 14 Tahun 2005 Tentang Guru dan Dosen" 228.
}

12 Evita, E., Syahid, A., \& Nurdin, N. (2019). Understanding Students' Learning Outcomes Differences Through the Application of the Market Place Activity Type of Cooperative Learning Model and the Application of Conventional Learning Models International Journal of Contemporary Islamic Education, 1(1), 6785.

e-ISSN: 2715-4572

p-ISSN: 2716-1439 
influential component in the creation of quality educational processes and outcomes.

Without the teacher, the learning objectives will not be achieved the maximum. During this time, Islamic education science books have introduced at least three words related to Islamic education: al-tarbiyah, al-ta' lim, and al-ta'dib. ${ }^{13}$ Below will be explained by each of these words:

1. Al-Tarbiyah

Abdurrahman An-Nahlawi argues that according to the Arabic dictionary, the At-tarbiyah pronunciation comes from three words: ${ }^{14}$

First, rabaa-yarbu, which means to grow and grow. And al-tarbiyah can mean the process of growing and developing what is in students, both physically, psychologically, socially, and spiritually.

Second, rabaa, yurbi, and tarbiyatan means growing (nasyaa) and becoming big or mature. By referring to this second word, tarbiyah means an effort to grow and mature students both physically, socially, and spiritually.

Third, rabba-yarubbu tarbiyatan, which means to improve (aslaha), master the affairs, maintain and care, beautify, give meaning, nurture, own, manage and preserve and its existence. By using these three words, tarbiyah means efforts to maintain, nurture, care for, improve, and regulate students' lives

13 Abuddin Nata, Ilmu Pendidikan Islam, (Jakarta: Kencana, 2010), 7.

14 Bukhari Umar, Ilmu Pendidikan Islam,(Jakarta:Amzah, 2010), 21-22. so that they can survive better in their lives. ${ }^{15}$

If the three words are compared or integrated with one another, the three words are mutually supporting and complementary. However, when viewed in terms of its use, it appears that the third term is more widely used. Furthermore, when the three words are integrated, understanding will be obtained that al-tarbiyah means the process of growing and developing potential (physical, intellectual, social, aesthetic, and spiritual) contained in students. So that they can grow and develop optimally, through maintaining, nurture, care for, improve and manage it in a planned, systematic and sustainable manner.

Thus, the word altarbiyah contains the scope of educational objectives, which is to grow and develop the potential and process of education that is to maintain, nurture, care for, improve, and regulate it.

2. Al-Ta'lim

The word al-talim, which means the plural, according to Hans Weher can mean Information, advice, instruction, schooling, teaching, training, education, and apprenticeship (work as an intern, study time for a skill). ${ }^{16}$ Abdul Jatah Falah further said that:

Ta'lim is the process of giving knowledge, understanding,

15 Lihat Abdul Mujib dan Jusuf Mudzakir, Ilmu Pendidikan Islam, (Jakarta: Prenada Media, 2006),10-11.

16 Abudin Nata, Ilmu Pendidikan Islam, (Jakarta: Kencana, 2010), 11.

e-ISSN: 2715-4572

p-ISSN: 2716-1439 
responsibility, and cultivation of trust, resulting in the purification (tazkiyah) or purification of human beings from all impurities that make them human beings in a condition that allows them to receive al-hikmah and learn everything that is beneficial to them and what they do not know. ${ }^{17}$

\section{Al-Ta'dib}

The word al-ta'dib comes from the words addaba, yuaddibu, ta'diban, which can mean education, discipline (obedient and subject to rules), punishment (warning or punishment), and chastisement (sanctification). ${ }^{18} \quad$ The word al-ta'dib comes from the word manners, which means civilized, politely polite, ${ }^{19,20}$ karma, manners, manners, morals, morals, and ethics. ${ }^{21}$

The word ta'dib is the gradual introduction and acknowledgment of human beings about the exact places of all things in the order of creation, thus leading to the recognition and acknowledgment of the power and majesty of God in its creation and existence.

\section{Al-Tahzib}

The word al-tahzib literally means moral education or purifying itself from bad deeds, and it means being well-

17 Bukhari Umar, Ilmu Pendidikan Islam,

24.

18 Abudin Nata, Ilmu Pendidikan Islam,

14.

19 Ibid.

${ }^{20}$ Rusli, R. (2009). Gagasan Khaled Abu Fadl tentang "Islam Moderat" versus "Islam Puritan" (Perspektif Sosiologi Pengetahuan). Jurnal Ilmiah Ilmu Ushuluddin, 8(1), 99-123.

21 Ibid. educated or well-maintained, and that means being a well being civil. 22

As a whole, the word al-tahzib is related to mental and spiritual improvement, moral, and that is to improve one's mentality, which is not in line with the teachings or norms of life to be in line with the teachings or norms. Improving their behavior to be good and respectable and improve their morals and character so that they become noble. The various activities include the field of educational activities. That is why the word al-tahzib also means education. ${ }^{23}$

According to Zakiyah Drajat, quoted by Muhammad Nurdin, the teacher is a professional educator because they implicitly volunteered to accept and shoulder some of the educational responsibilities that shouldered on the shoulders of parents. When a parent submits his child to school, it means that he has transferred his child's education to the teacher. This implies that they will not submit their children to unprofessional teachers, because not everyone can become a teacher. ${ }^{24}$

Teachers in Islam are responsible for children's development by striving for all their potential, affective, cognitive, and psychomotor potentials. Teachers also mean adults who are responsible for giving help to students in physical and spiritual development in order to reach the level of maturity, and be able to stand alone in fulfilling their duties as servants of God

\footnotetext{
22 Ibid, 15

${ }^{23} \mathrm{Ibid}, 16$.

${ }^{24}$ Muhammad Nurdin, Kiat Menjadi Guru Profesional, (Jogjakarta: Ruzz Media, 2008), 127. e-ISSN: $2715-4572$ p-ISSN: 2716-1439
} 
1. Definition of Islamic Religious Education

Education is a very important part of human life as a condition for achieving a better life in the future. The development and progress that is increasingly socialized among Indonesian people demand a balance of Islamic religious education.

Talking about Islamic Education can not be separated from the notion of education in general, because Islamic Education is the same as the notion of education in general, only the foundation used in Islam. In Indonesia Law No. 20 the year 2003 concerning the national education system, article 1 explains that:

Education is a conscious effort about planning to create an atmosphere of learning and learning process so that students actively develop their potential to have spiritual strength, self-control, personality, intelligence, noble character, and the skills needed by themselves, society, nation, and country. ${ }^{25}$

Education is an effort, direction, protection, and assistance given to the child aimed at the child's maturity, or more precisely helps so that the child is sufficiently capable of carrying out his own life's tasks. The influence comes from adults (or those created by adults such as schools, books, cycles of daily life, etc.) and is shown to people who are not yet mature.

${ }^{25}$ Undang-Undang Republik Indonesia Nomor 20 Tahun 2003 Tentang Sisdiknas (Bandung: Citra Umbara, Januari, 2006), 72.
According to KI Hajar Dewantoro that education is:

Demands in the life of growing children, the purpose of education is to determine allnatural forces that exist in these children so that they, as humans and as members of the community, can achieve the highest safety and happiness. ${ }^{26}$

Based on the above opinion, the authors conclude that education is a process of students that takes place continuously until the student reaches adult livelihood. This process takes place within a certain period. If the student has reached adulthood, they will be fully able to act alone for the welfare of his life and society. Thus, the understanding of Islamic Religious Education is a systematic and pragmatic efforts in helping students so that they live according to the teachings of Islam. ${ }^{27}$

The definition of Islamic Religious Education, according to experts, is:

a) According to Zakiyah Darajdat, it is believed that Islamic Religious Education is an attempt to enlighten and nurture learners so that they can always fully understand Islam, and then embrace the goal, which ultimately makes Islam a living point of view.

b) According to Tayar Yusuf, it is believed that Islamic Religious Education is a conscious effort of the

${ }^{26}$ Hasbullah, Dasar-dasar ilmu Pendidikan (Jakarta: Raja Gafindo Persada, 2001), 2-4.

27 Zuhairini, dkk, Metodologi Pendidikan Agama (Solo: Ramadhadi, 1993), 1.

e-ISSN: $2715-4572$

p-ISSN: 2716-1439 
older generation to transfer the experience, knowledge, and skills to the younger generation in order to become devout towards Allah SWT. ${ }^{28}$

c) According to Muhaimin, it is believed that Islamic Religious Education is a conscious effort to prepare learners to believe, understand, appreciate and practice Islam through guidance, teaching, and/or training on the right goals. ${ }^{29}$

As is the case with another science. Before further pointing out the direction and purpose, then the ideology needs to understand the meaning contained in it so that the real meaning can be known.

In an introduction to the philosophy of Islamic education, Ahmad D. Marimba said, "Education is the guidance or leadership consciously by educators on the physical and spiritual development of the educated towards the formation of the main personality". 30

So, it can be understood that the understanding stated above is a system that can be used to form a perfect human being, and has the ability to take attitude and wisdom. On the other hand, the meaning of Islamic Religious Education can be understood as something that can change the pattern of human life from the back then to advanced life.

${ }^{28}$ Abdul Majid, Dian Andayani, Pendidikan Agama Islam Berbasis Kompetensi (Bandung: PT

Remaja Rosdakarya, 2004), 130.

${ }^{29}$ Muhaimin, dkk, Paradigma Pendidikan Islam Upaya Mengefektifkan Pendidikan Agama Islam di Sekolah (Bandung: PT Renaya

Rosdakarya, 2001), 75-76.

${ }^{30}$ Ahmad D. Marimba, Pengantar Filsafat

Pendidikan Islam, (Cet. VIII, Bandung: PT. Al

Ma'arif, 1989), 19.
Education can also be interpreted as guidance to someone to be able to go to a better path.

\section{Methodology}

This study uses a qualitative approach with the object of research is the SMP Negeri 10 Palu. The reason that the authors chose the location of the study that is SMP Negeri 10 Palu because it is a school that has adequate facilities and infrastructure, so it is very appropriate to be used as a research location. With these advantages, it can be understood that the SMP Negeri 10 Palu has implemented innovative learning so that the location is very representative when associated with the Thesis Title.

The use of qualitative methods in this study with several considerations. First, adjusting qualitative methods is easier when dealing with multiple realities. Second, it can present the nature of the relationship between researchers and informants directly. ${ }^{31}$ Third, this method is more sensitive and adaptable to the many sharpening of shared directors and the patterns of values encountered. ${ }^{32}$

Data that we collected using observation techniques, in-depth interviews, and studies from various written documents. ${ }^{33}$ While the data

${ }^{31}$ Nurdin, N. (2017a). Research in Online Space: The Use of Social Media for Research Setting Jurnal Sistem Informasi (Journal of Information System), 13(1), 67-77.

${ }^{32}$ Ibid., 5.

${ }^{33}$ Nurdin, N. (2017b). To Research

Online or Not to Research Online: Using Internet-Based Research in Islamic Studies e-ISSN: 2715-4572 p-ISSN: 2716-1439 
analysis was carried out using reduction and verification techniques with various data sources. ${ }^{34}$ The reduced data was then analyzed by claiming to the theoretical concepts used in this study.

\section{Result and Discussion}

\subsection{Competencies of Islamic Religious Education Teachers}

As well known that in addition to the principal, the thing that is no less important in order to improve the quality of education in schools is the role, function, and responsibility of the teacher, bearing in mind that the teacher is the person directly dealing with students in implementing the subjects, so in the end, the education output can be felt by the community. This situation can be accomplished if supported by efforts to improve teachers' ability to manage and play a direct role in teaching and educating their students. Teachers are the foremost implementers of children's education in schools. Therefore, the success or failure of efforts to improve the quality of education is also largely determined by the teacher's ability to carry out the main daily tasks, namely the management of learning in schools.

There are four teachers in the SMP Negeri 10 Palu as the author interviewed

Context. Indonesian Journal of Islam and Muslim Societies, 7(1), 31-54.

${ }^{34}$ Nurdin, N. (2016). The Roles of Information Technology in Islamic Bank Knowledge Management: A study of Two Syariah Banks in Palu. Hunafa: Jurnal Studia Islamika, 13(2), 181-217.

https://doi.org/https://doi.org/10.24239/jsi.v1 3i2.444.181-217 with the Deputy Principal of SMP Negeri 10 Palu, as follows:

There are four teachers of Islamic Religious Education in the SMP Negeri 10 Palu, including Dra Djohariah, Dra Siti Jawariah, Dra Nur Huda S. Thahir, M.Pd.I and Mr. Topalino, S.Ag., M. Pd.I. Alhamdulillah, teachers in SMP Negeri 10 Palu, teach according to their scientific level, so that with the discipline that they have, they are more professional in teaching. Thus, learning objectives will be easier, and learning objectives will be achieved. ${ }^{35}$

As a result of the interview above, the writer concludes that there are four teachers of Islamic Education in SMP Negeri 10 Palu. Ms. Djohariah and Mrs. Siti Jawariah have S1 education qualifications, and Mrs. Nur Huda S. Thahir and Mr. Topalino have S2 education qualifications. Thus, it is expected that there are four teachers in SMP Negeri 10 Palu to be professional in learning so that learning objectives can be achieved in line with expectations.

As in this study, the authors do not explain one by one the competencies they have. The author will describe in general the competencies they have as the results of interviews in the field.

Professional teachers are teachers who have certain conditions fulfilled, as stated by Islamic Religious Education teachers in the SMP Negeri 10 Palu:

${ }^{35}$ Kuntoro Rapail, Wakil Kepala Sekolah Menengah Pertama (SMP) 10 Negeri Palu, "Wawancara," Ruangan Wakasek, tanggal, 20 Agustus 2015. 
As an educator who interacts with students every day, they must have good physical health, which means that teaching staff must be in good shape and do not have dangerous communicable diseases and have good spiritual health. This means that they do not experience mental disorders or abnormalities, having a mental attitude good towards the educational profession, love and serve, and has a high dedication to their duties and positions. Of course, having good morals, namely having noble character and having a high moral attitude, as well as intellectual, that is, having high knowledge and skills from educational institutions of educational staff, which provides provisions to fulfill their duties and obligations as educators. ${ }^{36}$

Thus, these conditions can be explored that the latter conditions are specific and only carried out specifically as well. Furthermore, to realize quality improvement by teachers based on their roles, functions, and responsibilities, of course, teachers will be faced with a number of problems including characteristics of different students, relatively limited learning media, lack of understanding of psychological aspects and background of students and lack of coordination between a teacher with the students' parents. Therefore, the existence of these problems will cause teachers to not be optimal in improving

${ }^{36}$ Djohariah, Guru Pendidikan Agama Islam di Sekolah Menengah Pertama (SMP) 10 Negeri Palu, "Wawancara," Ruangan Guru, tanggal, 8 Juni 2015. the quality of education, so teachers need to work closely with school principals and the community.

The teacher is one component of the six main components that are determinants of the implementation and success of an educational program, namely: 1) teachers, 2) students, 3) material/curriculum, 4) facilities and infrastructure, 5) management or management, and 6) environment. For this reason, teachers as learning agents are required to carry out the learning process as well as possible within the framework of educational development. To be able to carry out its functions properly, teachers are required to have certain conditions, one of which is competence, especially competencies that are directly related to learning activities, that are pedagogical and professional competencies.

The role of the teacher in carrying out their duties and responsibilities, then a teacher of Islamic Education must have a number of competencies or master a number of knowledge, attitudes, and skills related to their field of work. Competencies that must be possessed by teachers can include pedagogical competencies, personality competencies, social competencies, and professional competencies.

\section{Pedagogical Competence}

Pedagogical competence is related to the ability to manage to learn. There is a mastery of the characteristics of students, mastering theories and principles of learning, developing curriculum, utilizing learning technology, effective communication to e-ISSN: 2715-4572 p-ISSN: 2716-1439 
students, and organizing learning effectively and efficiently.

The pedagogical competence referred to in this study is the ability of students in-depth and the organization of learning that educates. As the results of the author's interview with the Deputy Principal of SMP Negeri 10 Palu as follows:

A teacher's pedagogical competence is characterized by his ability to organize a quality learning process, and his attitudes and actions can be made an example. Alhamdulillah, for Islamic Religious Education teachers in SMP Negeri 10 Palu already has that attitude. So that in the learning process and outside the learning of students slowly changes toward a positive direction. ${ }^{37}$

Next, the Islamic Religious Education teacher explained in the interview as follows:

As a teacher, of course, they must better understand the psychology of child development while learning in educating includes the ability to design learning, implement learning, assess the learning process and outcomes, and make continuous improvements. 38

${ }^{37}$ Kuntoro Rapail, Wakil Kepala Sekolah Menengah Pertama (SMP) 10 Negeri Palu, "Wawancara," Ruangan Wakasek, tanggal, 6 Juni 2015.

${ }^{38}$ Siti Jawariah, Guru Pendidikan Agama Islam di Sekolah Menengah Pertama (SMP) 10 Negeri Palu, "Wawancara," Ruangan Perpustakaan, tanggal, 6 Juni 2015.
Then explained again by Islamic Religious Education teachers in the interview as follows:

Teacher pedagogical competence is the ability of teachers in managing student learning which at least includes:

a. Understanding of students

The understanding of students is one of the pedagogical competencies that teachers must-have. There are four things that teachers must understand about their students: the level of intelligence, creativity, physical and growth, and development as well as the potential of students.

b. Ability to manage and carry out learning

Meanwhile, to manage learning situations, teachers must be able to design learning well so that learning objectives can be achieved as expected. In this case, the teacher tries to plan a learning system that utilizes available resources. So that all learning activities from start to finish can be planned strategically, including anticipating problems that are likely to emerge from the planned scenario. The plan is regulated in the scenario. While the implementation of learning is a process of interaction between students and the environment, resulting in a change in behavior towards a better direction. In this interaction, there are certain factors that influence both external and internal factors. Therefore, of course, in learning, the most important task from the teacher is to condition the environment to support changes in the formation of student competency behavior.

c. The ability to use learning technology 
Of course, in organizing learning, teachers use technology as a medium. Provide learning materials and administer using information technology. Accustom students to interact with technology. The educational facilities generally include facilities and infrastructure so that the improvement of educational facilities must be emphasized in increasing learning resources, both in quantity and quality, in line with the development of educational technology today.

d. The ability to carry out evaluations of learning outcomes

The evaluation of learning outcomes is carried out to find out changes and the formation of students' competencies, which can be done by classroom assessments, tests of basic abilities for the final assessment of education units, and program assessments.

e. Development of students

The development of students is part of the pedagogical competencies that teachers must have to actualize the various potentials possessed by each student. In this case, students' development can be done in a way, including extracurricular, enrichment, and remedial, as well as persuasive guidance for students with problems. ${ }^{39}$

Personality competence is a personal ability that is steady, noble, wise, and authoritative, as well as being a role model for students. Social competence is related to communication skills among fellow educators,

${ }^{39}$ Djohariah, Guru pendidikan Agama Islam di Sekolah Menengah Pertama (SMP) 10 Negeri Palu, "Wawancara," Ruangan perpustakaan, tanggal, 10 Juni 2015. educators, parents, and the community. In the context of the learning process in the classroom, Islamic Religious Education teachers who have professional abilities means that they can carry out the learning process effectively.

However, the challenges and responsibilities in the world of education in the future are not easy, so they always close ranks to prepare themselves to be part of the calculated learning community. In this regard, SMP Negeri 10 Palu is ready to deliver the academic community in particular and society, in general, to become better, quality, and have a competitive advantage in their fields.

The pedagogical competence of Islamic Religious Education teachers in SMP Negeri 10 Palu is relatively good because it is seen from the quality of education in SMP Negeri 10 Palu, increasing from year to year. When viewed from teachers who teach Islamic Religious Education, they already have competent pedagogical competencies in their fields, especially Islamic Religious Education teachers.

\section{Personality Competencies}

The personality competencies of teachers in SMP Negeri 10 Palu in the following interviews:

Teacher's personal competence at SMP Negeri 10 Palu already has a stable, mature, wise, dignified, and noble character. It is also expected to foster teacher independence in carrying out 
tasks and is always accustomed to building a work ethic. ${ }^{40}$

The teacher is not only a teacher, trainer, and supervisor, but also as a mirror where students can look in the mirror. In the interpersonal relationship between the teacher and the student's subject, the situation of the student is created, which allows the student's subject to learn to apply the values that become examples and give examples. The teacher is able to be a person who understands students with all the problems. The teacher must also have the authority so that students are reluctant to do so. The nature of teacher educators is that they are innocent and imitated.

The teacher's personality is determined by the morals that they have because all of the teacher's behavior or morals will be noticed by their students, and this will greatly affect the authority of a teacher. Therefore, a teacher must have a good character.

The understanding of a teacher who has a steady and stable personality is an individual who has consistency in acting according to legal norms, social norms, and ethics that apply, both in the school environment and the school itself. Therefore, on one hand, a teacher must show proactiveness as an individual community, and on the other hand, the role and status inherent in him must be highlighted.

${ }^{40}$ Luter, Guru Bahasa Indonesia di Sekolah Menengah Pertama (SMP) 10 Negeri Palu, "Wawancara," Ruangan Wakasek, tanggal, 6 Juni 2015.
One example of good behavior expressed by students is that Islamic education teachers always start teaching in a timely manner. Other students also state that teachers sometimes start on time.

Analyzing the answers of these students, one thing that is inherent in the status of Islamic Religious Education teachers in SMP Negeri 10 Palu is good behaviors, fortitude, patience and interestingly are the demands of the community indirectly for an individual teacher of religion Islam in order to display all of these things in everyday life.

Regarding the teacher's behavior, what is desired in the teacher's personal capacity standard is the expectations that process. This was stated by a student, Nurul Islami class VIII E (14 years old) that:

The religion teacher can pay attention to examples of good behavior. It is our hope, especially religion teachers know everything related to good and bad things. Thus, the teacher can advise us, for example, the teacher teaching on time naturally affects other friends not to be late to class. ${ }^{41}$

From the interview above, the author concludes that an Islamic religion teacher with the status he has will certainly behave to students because the teacher is a figure who is innocent and imitated. Other indicators of teacher personality are "adult" in all respects.

41 Nurul Islami, Peserta didik Sekolah Menengah Pertama (SMP) Negeri 10 Palu kelas VII, wawancara dikelas, pada tanggal 06 Januari 2013.

e-ISSN: 2715-4572

p-ISSN: 2716-1439 
The understanding included in it is that when faced with a problem or phenomenon, a teacher must treat or display behavior that is in accordance with the phenomenon. In this context, a teacher is required to pay attention to the right attitude, both in the classroom and outside the classroom and even in the environment of society. Another understanding is to have the independence to act as an educator and to have a work ethic as a teacher.

\section{Professional Competence}

Furthermore, after the teacher has professional abilities that support the role and function, the strategies that can be carried out in connection with efforts to improve the quality of education include: the implementation of learning more activating learners' learning, overall attention to all students, understanding the different characters of each student, utilizing the environment as a source of learning and carry out an overall evaluation of the learning outcomes of students. Considering the importance of the role of teachers in efforts to improve the quality of education. Especially in the implementation of learning, it is appropriate that the ability to be improved, fostered well and continuously so that they have the ability in accordance with the demands of their profession.

As the results of the interview stated as follows:

Professional teachers must have skills in managing classes that are the teacher's task in learning activities by providing optimal learning conditions. Optimal learning conditions can be achieved if the teacher can arrange students and teaching facilities to achieve learning objectives. Alhamdulillah, teachers at SMP Negeri 10 Palu, have tried to make them professional teachers in their respective fields. ${ }^{42}$

Professional work is supported by a particular knowledge in depth, which can only be obtained from appropriate educational institutions so that its performance is based on the knowledge it has that can be scientifically justified. A profession emphasizes expertise, in certain specific fields appropriate to the type of profession, so that one can be separated from one another.

The intended professional competence is the ability to master extensive and in-depth learning material. The professional competencies that must be possessed by a teacher include mastering the foundation of education, in this case, knowing the purpose of national education, knowing the function of schools in society, and knowing the standards of basic competencies and competency indicators in learning. Mastering subject matter, in this case, mastering curriculum material to be taught, mastering relevant supporting material relevant to the material to be taught, and mastering language correctly and adequately.

The implementation of Islamic Religious Education learning in the

42 Luter, Guru Bahasa Indonesia di Sekolah Menengah Pertama (SMP) 10 Negeri Palu, "Wawancara," Ruangan Guru, tanggal, 12 Agustus 2015.

e-ISSN: 2715-4572

p-ISSN: 2716-1439 
curriculum is only 2 hours of learning, but if calculated in terms of its implementation and practices it can be more, this is done in addition to learning in class, there are also other religious activities that support, such as recitation on Thursday and Sunday, eradication of the illiteracy of the Al-Qur'an which is carried out on Thursday Ba'da Magrib until Ba'da Isya. ${ }^{43}$

The essence of the above statement is the implementation of Islamic Religious Education learning in SMP Negeri 10 Palu. It is carried out for more than 2 hours per week, and this is the accumulation of the implementation of Islamic Education learning that is carried out in class and outside the classroom.

\section{Social Competence}

This social competence is very important to be owned by an educator in undergoing social interaction. Because with social competence in communicating, the conversation is pleasant to hear, good at talking and sociable, easy to work together, not easily upset, not easily discouraged, and smart in managing their emotions. Therefore, an educator's social competence is the basis for the educator concerned in carrying out a teacher's job professionally.

The task of teaching is not just to convey information but a process of changing the behavior of students in accordance with the expected goals.

43 Observasi, di Sekolah Menengah Pertama (SMP) Negeri 10 Palu, Tanggal 19 Agustus 2015.
Therefore, in the teaching process, there are activities to guide students so that students develop according to their development tasks, train skills, both intellectual and motor skills so that students can live in a fast-changing and competitive society, motivating students in order to stay motivated to face challenges and obstacles, the ability to design and use various media and learning resources to increase the effectiveness of teaching, and so forth.

The social competencies possessed by Islamic Religious Education teachers in SMP Negeri 10 Palu in interviews as follows:

The social competence of teachers in SMP Negeri 10 Palu is fairly good because the social competencies referred to here are the abilities and skills that teachers have in relation to interactions with other people. This means that teachers must have the skills to interact with anyone, both fellow teachers, students, and the community. Thus when problems occur, it is easy to identify, analyze, and find a way out of each problem that arises. ${ }^{44}$

As the interview results above, the writer concludes that this social competence is very important to have for a teacher in conducting social interaction because by having this competence in communicating pleasantly, does say bad words, articulate, easy to get along, easy to

44 Luter, Guru Bahasa Indonesia di Sekolah Menengah Pertama (SMP) 10 Negeri Palu, "Wawancara," Ruangan Guru, tanggal, 12 Agustus 2015.

e-ISSN: 2715-4572

p-ISSN: 2716-1439 
cooperate, patient, not easily upset, not easily discouraged and smart in managing his emotions. While people with low social competence often make the people around them feel uncomfortable because of their arrogance and harsh words. Thus, the social competence of an educator is the basis for the educator concerned in carrying out his teacher's job professionally because basic educational activities are the specialization of personal communication between educators and students.

As a teacher, they must be able to present themselves in such a way that their presence can be accepted in the community. In this way, educators will be able to work well with school committee boards both inside and outside the classroom.

\subsection{Teacher's Efforts in Improving the Quality of Education}

In connection with the role and function of teachers in learning, it is necessary to have an effort from the teacher to optimize the roles and functions. The teacher's role will always describe the expected behavior patterns in various interactions, both with students, fellow teachers, and school staff, or even with the principal. From a variety of interactive activities, the learning activities can be seen as central to its role, bearing in mind whether or not it is realized that part of the teacher's time and attention is devoted to the cultivation of learning in the classroom and interacting with students.

In this study, identify the efforts taken by Islamic religious education teachers in the research location in order to shape the character of students. Following up on these problems, the author's interviews with a number of teachers with the intention of revealing the steps taken by them. The author has identified a number of steps taken by the teachers of SMP Negeri 10 Palu, they are:

a. Providing guidance to students

Tutoring for students meaning providing assistance to students in making choices wisely and in adjusting to the demands of life, so that students are more focused in learning and responsible in assessing their own abilities and use their knowledge effectively for themselves, and have the potential that develops optimally covers all aspects of his personality as a potential individual. In addition, the provision of guidance is also assistance given by teachers to students to solve the problems they face.

As the author's interview with students named Angga Nuardi class VIII $F$ revealed the importance of the guidance that the teacher gave him, that:

Tutoring is a very influential thing for me because, through the guidance of the teacher providing suggestions such as reminding me to study harder at home, I do it by creating an atmosphere of discussion at home. Apparently, in this way, there are many benefits that I feel, among others, expanding horizons and training to convey ideas well and create appreciation. My parents were involved in helping the teacher at home. 44

e-ISSN: 2715-4572

p-ISSN: 2716-1439 
The interview description above strongly recommends the guidance of the teacher. Psychologically this will be responded by students as participants and students.

\section{b. Giving Advice}

Another form of effort for Islamic Religious Education (PAI) teachers is advising students. Giving advice means giving suggestions or input to solve a problem based on knowledge, experience, and common sense. Advice has a considerable influence in opening children's eyes to the awareness of the nature of something and encourage them to do something good.

Advice is given by the teacher every time they meet anywhere. Thus, students can feel the efforts made by the teacher to make students progress in everything, including learning, so that children can improve their learning achievement.

The action above was confirmed by the teacher of SMP Negeri 10 Palu:

I realize that teachers must guide their students more whenever they want to learn and finish studying in class. To create a better atmosphere of intimacy between educators and students, as educators, of course, in interacting with students, they must be more observant in seeing students' situations. When students make mistakes, they will be given sanctions related to mistakes made, giving sanctions aimed at making students do not do something a second time. ${ }^{45}$

Expressed by students of SMP Negeri 10 Palu as follows:

In an effort to provide guidance, in addition to providing advice, sometimes also punishment is given if students do something wrong, for example, when lazy to study or lazy to go to school. 46

From the above interview, it is illustrated that the purpose of giving a penalty or sanction is to stop the bad behavior, and the next goal is to educate and encourage students to stop the bad behavior themselves.

Besides that, the punishment given is still reasonable, logical, objective, and does not burden the mentality and must be comparable between the mistakes made and the punishment is given. If the punishment is too severe, then students tend to avoid or leave.

c. Supervision towards students

Supervision is carried out in an open and continuous manner that is known to all parties. Various things planned in SMP Negeri 10 Palu are the embodiment of schools that have implemented elements of openness, responsibility/accountability, and participation. It is done by planning,

45 Djohariah, Guru Pendidikan Agama Islam di Sekolah Menengah Pertama (SMP) 10 Negeri Palu, "Wawancara," Ruangan Guru, tanggal, 8 Juni 2015.

46 Angga Nuardi, Peserta didik di Sekolah Menengah Pertama (SMP) 10 Negeri Palu, “Wawancara," Ruang Tamu, tanggal, 28 Juli 2015.

e-ISSN: $2715-4572$

p-ISSN: 2716-1439 
implementing, and supervising while involving all elements within the scope of the school and the community.

Supervision of students is very important in seeing the level of development of students from various aspects. Teacher supervision includes monitoring, evaluating, reporting, and following up on supervision results. Management monitoring is carried out by the principal, teachers continuously to assess the efficiency, effectiveness, and accountability of education management.

Evaluation of the supervision of academic management is carried out by school principals and school supervisors in a planned manner in accordance with the supervision program that has been prepared at the beginning of the school year to carry out the duties and functions of teachers. Supervision is the task of a school principal.

Various supervision carried out by various parties aims to find various problems and find solutions if there are programs that cannot be implemented. In other words, supervision is carried out to find a way out in solving problems, both work programs, and cost management.

This is as stated by Islamic Religious Education teachers as follows:

Various supervision of students conducted aims to find a joint solution if there are problems related to students. Besides that, supervision is carried out to prevent unintended violations. As a teacher, I strongly support the existence of such supervision, so we can find out the shortcomings and then find a way out. 47

Supervision conducted by the teacher, especially related to the implementation of the teaching and learning process, is welcomed by students. Students assume that with the continuous supervision of the teacher, the students can increase their ability to carry out tasks as students.

If one semester is to be assessed for factors that do not support, the school must improve the implementation of quality improvement programs in the following semester. A mid-term evaluation is carried out at the end of each year to determine how far the quality improvement program has achieved the quality goals that have been set previously. Through this evaluation, the program's strengths and weaknesses will be identified to be improved in the following years.

Teacher supervision means controlling or supervising all activities or activities that are being carried out by students both directly and indirectly. Teacher supervision is intended as a reinforcement of discipline so that children's education is not neglected, because neglect of a child's education will harm not only himself but also his environment.

Teacher supervision of students is usually preferred in learning and social problems. By supervising students in terms of learning and relationships, teachers can control the problems that

47 Djohariah, Guru Pendidikan Agama Islam di (SMP) 10 Negeri Palu, "Wawancara," Ruangan Perpustakaan, tanggal, 28 Juli 2015.

e-ISSN: $2715-4572$

p-ISSN: 2716-1439 
occur so that preventive action can be taken. ${ }^{48}$

Basically, teacher supervision does not mean restraint of children's freedom to be creative but rather emphasizes the supervision of children's free and responsible obligations. Supervision or control is carried out not only when in school, but also when students are outside the school environment.

\section{d. Providing motivation and appreciation}

As the primary educator, teachers are also required to be able to provide motivation and encouragement, because the task of motivating learning is the teacher's responsibility, to encourage students' enthusiasm for learning teachers should be able to give a kind of gift to increase learning interest for students themselves. But if the child's learning achievement is bad or lacking, the teacher's responsibility is to provide motivation or encouragement to students to be more active in learning.

As stated by Islamic Religious Education teachers in the interview as follows:

I think our encouragement as educators to children whether their achievement is unsatisfactory or is lacking and is very necessary because the lack of dissatisfaction or the lack of encouragement may increase less than satisfying achievements and may even lead to decisions. This

48 Observasi, di Sekolah Menengah Pertama (SMP) Negeri 10 Palu, Tanggal 20 Agustus 2015. action, we do whether our children perform well or not good. What we do, among others, is directing how to study, and managing study time, and so on. 49

Another form of teacher appreciation besides giving compliments is by giving a kind of gift or something like that. This prize is intended to provide students motivation, encourage, and increase trust in students themselves, as well as to strengthen relationships with them. However, the teacher also gives advice about the gift because it can also distort students' minds from actual learning goals.

e. Using teaching varies of methods

This step is generally taken by a teacher to overcome students' boredom and present a conducive classroom atmosphere. The steps taken by Islamic Religious Education teachers at the research location are using multimethods such as lecture method interspersed with Question and Answer methods or exploration methods.

Based on the results of interviews with Islamic Religious Education teachers stated:

When teaching class, the responses of diverse students are lacking attention and enthusiasm. However, the use of various teaching methods turns out to be interesting for students, especially if there are questions and answers 
or discussions about daily life about the actual theme. ${ }^{49}$

The interview results indicate that the use of varied learning methods can help students learn better, classes are more conducive, not boring, and so on.

f. Taking a personal approach towards students

In connection with the teachers' role and function in learning, it is necessary to have an effort from the teacher to optimize the roles and functions. The teacher's role will always describe the expected behavior patterns in various interactions, both with students, fellow teachers, and school staff, or even with the principal. From a variety of interactive activities, the learning activities can be seen as central to its role, bearing in mind whether or not it is realized that part of the teacher's time and attention is devoted to the cultivation of learning in the classroom and interacting with students.

One of the teacher's strategic steps is to take a personal approach to students, both directly and through the parents of the students concerned. The aim is to track down any constraints experienced by students and their friends. The results can be used as evaluation material to provide appropriate action for students.

\section{Conclusions}

Based on the formulation of the problem that has been determined and is associated with the results of the

49 Djohariah, Guru Pendidikan Agama Islam di (SMP) 10 Negeri Palu, "Wawancara," Ruangan Perpustakaan, tanggal, 28 Juli 2015. research description. It can be concluded that the competence of Islamic Religious Education teachers in SMP Negeri 10 Palu is adequate in terms of the pedagogical competence of Islamic Religious Education (PAI) teachers capable of managing student learning. Teacher personality competencies already have good personalities, are stable, mature, wise, authoritative, and have good character and are expected to grow the teacher's independence in carrying out tasks and are always accustomed to building a work ethic. The social competence of Islamic Religious Education (PAI) teachers is very good because the teachers here already have the abilities and skills related to the interaction with other people. Professional competence is sufficient but there are still teachers who still need to improve performance to be more professional in learning.

The efforts of Islamic Religious Education teachers in improving the quality of education in SMP Negeri 10 Palu is to provide guidance to students, give advice, supervise students, provide motivation and appreciation, use varied teaching methods, and take a personal approach to students.

\section{REFERENCES}

Amir, Jusuf, Faisal, Reorientasi Pendidikan Islam, Cet. 1; Jakarta : Gema Insani Press, 1995.

Asy'ari, M, Konsep Pendidikan Islam, Implementasinya dalam Tradisi Klasik dan Propagasi Modern, Jakarta : Rabbani Perss, 2011.

e-ISSN: 2715-4572

p-ISSN: 2716-1439 
Burhan Bungin, Peneiltan Kualitatif, Komunikasi, Ekonomi, Kebijakan Publik, dan Ilmu Sosial lainnya, Cet. I; Jakarta: Kencana Prenada Media Group, 2007.

Chalil, Moenawar, Kelengkapan Tarikh Nabi Muhammad, Jakarta, Gema Insane,2001.

Danim, Sudarwan, Pedagogi, Andragogi, dan Heutagogi, Bandung: Alfabeta, 2010.

Darajat, Zakiah, Metodik Khusus Pengajaran Agama Islam, Jakarta: PT Bumi Aksara, 2011.

Departemen Agama RI, Alquran dan Terjemahnya, Bandung: Jumatul Ali Art, 2007.

Departemen Agama RI , Al-Qur'an dan Terjemahnya, Jakarta: Darus sunnah, 2002.

Departemen Pendidikan Nasional, Kamus Besar Bahasa Indonesia, Cet. II; Jakarta: Balai Pustaka, 2005.

Djaali, Psikologi pendidikan, Jakarta: PT Bumi Aksara, 2008.

Ezmir, Metodologi Penelitian Kualitatif Analisis Data, Cet.II Jakarta: PT. Raja Grafindo Persada, 2011.

Evita, E., Syahid, A., \& Nurdin, N. (2019). Understanding Students' Learning Outcomes Differences Through the Application of the Market Place Activity Type of Cooperative Learning Model and the Application of Conventional Learning Models International Journal of Contemporary Islamic Education, 1(1), 67-85.

Hamalik, Oemar Pendidikan Guru Berdasarkan Pendidikan Kompetensi, Jakarta; PT Bumi Aksara, 2009.
Hamalik, Oemar, Pendidikan Guru Berdasarkan Pendekatan Kompotensi Cet. V, Jakarta : Bumi Aksara, 2008.

Hasbullah, Dasar-Dasar ilmu Pendidikan, Jakarta: Raja Gafindo Persada, 2001.

Imron Arifin, Penelitian Kualitatif dalam Ilmu-ilmu Sosial dan Keagamaan, Cet. III Malang: Kalimasada Press, 1996.

Irawan Suhartono, Metode Penelitian Sosial, Cet. V; Bandung: Remaja Rosdakarya, 2002.

Isjoni, Guru sebagai Motivator Perubahan, Yogyakarta: Pustaka Pelajar, 2009.

Kementerian Agama RI, Alquran dan Terjemahnya, Bandung: Jumatul Ali Art, 2007.

Kementerian Agama RI, Al-Qur'an dan Tafsimya, Jakarta: Lentera Abadi, 2010.

Kunadar, Guru professional Implementasi Kurikulum Tingkat Satuan (KTSP), Jakarta: PT Raja Grafindo,2007.

M. Ali Hasan, Et. Cil. Kapita Selekta Pendidikan Islam, Cet, I : Jakarta:Pedoman Ilmu jaya, 2005.

Majid, Abdul, Dian Andayani, Pendidikan Agama Islam Berbasis Kompetensi Bandung: PT Remaja Rosdakarya, 2004.

Margono, S, Metode Penelitian Pendidikan, Cet. II; Jakarta: Rineka Cipta, 2000.

Marimba, Ahmad D, Pengantar Filsafat Pendidikan Islam, Cet. VIII, Bandung: PT. Al Ma'arif, 1989.

Milles, Metthew B, dan A. Michael Hubarman, Qualitative Data Analisis, diterjemahkan oleh Tjecep Rohendi, Analisis Data e-ISSN: 2715-4572 p-ISSN: 2716-1439 
Kualitatif. Buku Tentang Metodemetode Baru, Cet. I; Jakrta: UI Press, 2005.

Moleong, Lexy J, Metodologi Penelitian Kualitatif, Cet. XIV; Bandung: Remaja Rosda Karya, 2001.

Moleong, Lexy J, Metodologi Penelitian Kualitatif, Cet. XVII; Bandung: PT. Remaja Rosdakarya, 2002.

Muhaimin, dkk, Paradigma Pendidikan Islam Upaya Mengefektifkan Pendidikan Agama Islam di Sekolah, Bandung: PT Renaya Rosdakarya, 2001.

Muhaimin, Paradigma Pendidikan Islam, Upaya Mengaktifkan Pendidikan Islam di Sekolah, Bandung: Remaja Rosdakarya, 2002.

Muhaimin, Pengembangan Kurikulum Pendidikan Agama Islam di Sekolah, Madrasah dan Perguruan Tinggi, Jakarta: PT Raja Grafindo Persada, 2008.

Muhibbin Syah, Psikologi Pendidikan Suatu Pendekatan Baru, Cet. II; Bamdung, Remaja Rosdakarya, 1995.

Mulyasa, E, Standar Kompetensi dan Sertifikasi Guru, Bandung: PT Remaja Rosdakarya, 2009.

Mulyasa, E, Standar Kompotensi dan sertifikasi Guru, Cet: I; Bandung: PT Remaja Rosdakarya, 2007.

Mungin Eddy Wibowo "Sertifikasi Profesi Pendidikan" http: // www.suara merdeka.com/harian/0602/opi,0 4,htm,hlm.1, diunduh pada 27 Desember 2014.

Naim, Ngainum, Menjadi Guru yang Inspiratif, Yogyakarta:Pustaka Pelajar, 2011.
Nata, Abudin, Ilmu Pendidikan Islam, Jakarta:kencana, 2010.

Nurdin, Muhammad, Kiat Menjadi Guru Profesional, Jogjakarta: Ruzz Media, 2008.

Nurdin, N. (2016). The Roles of Information Technology in Islamic Bank Knowledge Management: A study of Two Syariah Banks in Palu. Hunafa: Jurnal Studia Islamika, 13(2), 181217.

https:/ / doi.org/https:/ / doi.org/ 10.24239/jsi.v13i2.444.181-217

Nurdin, N. (2017a). Research in Online Space: The Use of Social Media for Research Setting Jurnal Sistem Informasi (Journal of Information System), 13(1), 67-77.

Nurdin, N. (2017b). To Research Online or Not to Research Online: Using Internet-Based Research in Islamic Studies Context. Indonesian Journal of Islam and Muslim Societies, 7(1), 31-54.

Pemerintah RI, UU RI Nomor 20 Tahun 2003 tentang Sistem Pendidikan Nasional , Jakarta : PT. Kloang Klede Putra Timur dan Koperasi Primer Praja Mukti, 2003.

Rahman, Getteng, Abd, Menuju Guru Profesional dan Ber-Etika, Yogyakarta: Grha Guru, 2013.

Ramayulis, Profesi dan Etika Keguruan, Jakarta: Kalam Mulia, 2013.

Robert C. \& Stren J. Tailor, Kualitatif, Dasar-Dasar Penelitian, Usaha Nasional, 1993.

Ruslan, Rosady, Metode Penelitian Public Relation dan Komunikasi, Cet. IV; Jakarta: PT. Raja Grafindo Persada, 2004.

e-ISSN: 2715-4572

p-ISSN: 2716-1439 
Rusli, R. (2009). Gagasan Khaled Abu Fadl tentang "Islam Moderat" versus "Islam Puritan" (Perspektif Sosiologi Pengetahuan). Jurnal Ilmiah Ilmu Ushuluddin, 8(1), 99123.

Rusyan, et. Al. Attabrani, Propesonalisme Tenaga Kependidikan, Bandung :Nine karya, jaya, 1995.

Sadulloh, Uyoh, Pedagogik Ilmu Mendidik, Bandung: Alfabeta, 2010.

Sanusi, Ahmad, Profesionalisme Tenaga Pendidikan, Cet,I. Jakarta: Nine Karya Jaya, 1992.

Sudiyono, Ilmu Pendidikan Islam, Jakarta:Rineka Cipta, 2009.

Sugiyono, Metode Penelitian Kuantitatif, Kualitatif dan $R$ \& $D$, Cet.VI; Bandung: Alfabeta, 2009.

Sumardi dalam Ramayulis, Profesi dan Etika Keguruan, Jakarta: Kalam Mulia, 2013.

Syaifudin, Udin, Pengembangan Profesi Guru, Bandung: Alpabeta, 2010.

Tilaar, Beberapa Agenda Reformasi Pendidikan Nasional, Jakarta: Tera Indonesia, 2001.

Tim penyusun kamus pusat bahasa, Kamus besar bahasa Indonesia, Jakarta: Balai Pustaka,2005.

Trianto, Pengantar Penelitian Pendidikan bagi Pengembangan Profesi Pendidikan dan Tenaga Kependidikan, Jakarta: Prenada Media Group,2010.

Umar, Bukhari, Ilmu Pendidikan Islam,Jakarta: Amzah, 2010.

Umar, Husein, Metode Penelitian untuk Skripsi dan Tasir Bisnis, Cet. IV ; Jakarta: PT. Raja Grafindo, 2000.

Undang-Undang Republik Indonesia Nomor 20 Tahun 2003 Tentang
Sisdiknas Bandung: Citra Umbara, Januari, 2006.

Undang-undang RI No 14 Tahun 2005 \& PP RI No 74 Tahun2008 tentang Guru dan Dosen, Bandung: Citra Umbara, 2009.

Uzer, Usman, Moh, Menjadi Guru Profesional, Bandung,: PT Remaja Rosdakarya, 1999.

Winkel, Psikologi Pengajaran, Jakarta: PT Gramedia, 1989.

Yin, Robert K, Case Study Design and Methods, diterjemahkan oleh M. Djauzi Mudzakir dengan judul: Studi Kasus Desain dan Metode, Cet.I Jakarta: PT.Raja Grafindo Persada, 2002.

Zuhairini, dkk, Metodologi Pendidikan Agama, Solo: Ramadhadi, 1993. 